\title{
National guidelines for physical activity in early childhood in American countries: a scoping review
}

\author{
Guias nacionais de atividade física para crianças na primeira infância nos países \\ americanos: revisão de escopo
}

\section{AUTHOR'S \\ Paulo Henrique Guerra ${ }^{1}$ (D) \\ Anastácio Neco de Souza Filho ${ }^{2}$ (D) \\ Carla Menêses Hardman ${ }^{3}$ (D) \\ Clarice Lucena Martins ${ }^{2}$ (D) \\ Daniel da Rocha Queiroz ${ }^{3}$ (D) \\ Larissa Rosa da Silva ${ }^{4}$ (D) \\ Paula Fabricio Sandreschi ${ }^{5}$ (D) \\ Rildo de Souza Wanderley Junior ${ }^{3}$ if \\ Daniel Umpierre ${ }^{6}$ (D) \\ Mauro Virgilio Gomes de $\operatorname{Barros}^{7}$ (D) \\ 1 Federal University of Fronteira Sul, Chapecó, Santa Catarina, Brasil. \\ 2 Federal University of Paraíba, Department of Physical Education, João Pessoa, Paraíba, Brasil. \\ 3 Federal University of Pernambuco, Department of Physical Education, Recife, Pernambuco, Brasil. \\ 4 State University of Western Paraná, Department of Physical Education, Marechal Cândido Rondon, Paraná, Brasil. \\ 5 Ministry of Health, Secretariat of Primary Health Care, Health Promotion Department, General Coordination of Physical Activity Promotion and Intersectoral Actions, Brasília, Distrito Federal, Brasil. 6 Federal University of Rio Grande do Sul, Department of Collective Health, Porto Alegre, Rio Grande do Sul, Brasil. \\ 7 University of Pernambuco, Higher School of Physical Education, Recife, Pernambuco, Brasil. \\ CORRESPONDING}

Paulo Henrique Guerra paulo.guerra@ufs.edu.br

Rodovia SC 484, Km 02, Chapecó, Santa

Catarina, Brasil.

Zip Code: 89815899

\section{DOI}

10.12820/rbafs.26e 0228

\section{(cc) BY}

This work is licensed under a Creative Commons Attribution 4.0 International License.

\begin{abstract}
Our aim was to identify and analyze national guides with recommendations for physical activity for early childhood in the countries of the American continent. A scoping review was carried out on the websites of the national education, sport, and/or health agencies of the 36 American countries, on the Google website, and through contact with professionals. The synthesis was developed from the exploration of the material, looking for approaches and recommendations in the domains "benefits", "dose", "types and examples", "practice guidelines" and "sedentary behavior". From 21 documents initially assessed, four composed the synthesis (Canada, Chile, United States and Uruguay). All included guides converged on recommendations about the importance of physical activity for weight control and healthy growth and development (e.g., benefits domain); the importance of children being physically active at various times of the day, highlighting the provision of "joyful, safe, supervised, and age-appropriate physical activity" and "participation in structured-play activities" (e.g., types and examples domain); support for the provision of "fun, safe, supervised, and age-appropriate physical activity" (e.g., types and examples domain) and the support from parents or caregivers to stimulate activities that encourage responsibility and autonomy (e.g., practice orientation domain). Finally, considering that strategies to promote physical activity involve addressing individual and contextual factors, it is important that future national guides for physical activity involve recommendations in domains that are determinants of physical activity in this age group, such as support from primary caregivers and the built environment, in its access and possibilities.
\end{abstract}

Keywords: Physical activity; Public policy; Health promotion; Review.

RESUMO

Objetivou-se identificar e analisar guias nacionais com recomendaçôes de atividade física para a primeira infância nos países do continente americano. Foi realizada uma revisão de escopo nos sítios eletrônicos das agências nacionais de educação, esporte elou saúde dos 36 países americanos, no sitio eletrônico Google e por meio de contatos com profissionais. A sintese foi elaborada a partir da exploração do material, visando abordagens e recomendaçôes nos dominios "benefícios", "dose", "tipos e exemplos", "orientaçôes para a prática" e "comportamento sedentário". De 21 documentos avaliados, quatro foram encaminhados para a síntese (Canadá, Chile, Estados Unidos e Uruguai). Todos os guias incluídos convergiram quanto às recomendaçôes sobre a importância da atividade física para controle do peso e para o crescimento e desenvolvimento saudáveis (e.g., dominio benefícios); sobre a importância das crianças serem fisicamente ativas em vários momentos do dia, destacando a oferta de "atividades físicas alegres, seguras, supervisionadas e adequadas à idade" e a "participaçẫo em jogos, brincadeiras e atividades estruturadas" (e.g., dominio tipos e exemplos); e sobre o apoio dos pais e responsáveis ou dos cuidadores ao estímulo de atividades que incentivem a responsabilidade e a autonomia (e.g., dominio orientação para a prática). Por fim, considerando que estratégias de promoção de atividade física envolvem a abordagem de fatores individuais e contextuais, é importante que futuros guias nacionais de atividade física envolvam recomendaçôes em domínios que são determinantes da atividade física nesta faixa etária, como o suporte dos cuidadores primários e o ambiente construído, em seu acesso e possibilidades.

Palavras-chave: Atividade física; Política pública; Promoção da saúde; Revisão.

\section{Introduction}

In the context of public health, "guidelines" are documents that provide a structured and systematic set of evidence-based recommendations on a particular health topic ${ }^{1}$. In order to direct people to adopt healthy habits, based on an accessible language, these do- 
cuments are also considered a public policy, as goals, targets and parameters are agreed upon for monitoring and evaluating the indicators of interest, as a guiding document for the planning and development of scientific studies ${ }^{2,3}$.

Physical activity (PA) plays an important role in human development ${ }^{4}$, at different times in the life cycle. In particular, the extensive body of studies suggests that physical activity is directly related to several health benefits in early childhood (period between 0 and 6 years of age) which is considered a time of rapid physical, motor and cognitive development, in addition to being a time in which habits related to lifestyle begin to be established ${ }^{4,5}$.

Recognizing that active children are more likely to become active adolescents and adults ${ }^{6}$, it is recommended that physical activity be encouraged from the first months of life ${ }^{7}$. In this sense, some countries already have guidelines that address recommendations for physical activity in early childhood ${ }^{8}$, also involving other related behaviors, such as screen time and sleeping'.

Given the potential of guides to inform the general population about the main aspects related to their practice, it is important to recognize and study their recommendations, in order to allow debate on several fronts, from their formats, objectives and related intentions regarding physical activity to ways and strategies for its better dissemination in the community context ${ }^{3}$.

Thus, this study aimed to identify which countries in the Americas have national physical activity guidelines with recommendations for early childhood and analyze the available recommendations.

\section{Methods}

This work was conducted for the purposes of the Physical Activity Guidelines for the Brazilian Population, which was approved and financed by the Brazilian Ministry of Health (project: 79224219002/2019; process: $25000.171034 / 2019-27) 10$. The evidence produced by this review was used as one of the supporting references for the recommendations in the chapter entitled "Physical activity for children up to 5 years old"11.

Its registration was made on the Open Science Framework platform (DOI 10.17605/OSF.IO/YTZ$\mathrm{BG}$ ) and its report was prepared in accordance with the items on the PRISMA checklist (available at: http:// www.prisma-statement.org/Extensions/ScopingReviews). The document that indicates the answered items of PRISMA and their respective positions in the article text can be accessed in Supplementary Material 1.

Between June and September 2020, a scoping review was conducted, which, as inclusion criteria, sought national physical activity guides endorsed by national education, sport or health agencies, which contained recommendations aimed at children in early childhood (eg, guides specific or not for this stage of life). Recognizing the divergence between the guides regarding the age groups that characterize early childhood, age was not adopted as an exclusion criterion, as long as the guides presented specific recommendations for this stage of life ${ }^{8}$.

More specifically, "guides" were characterized as informative documents, with accessible language and the objective of guiding the population in relation to the practice of physical activity, regardless of the topics covered, such as, for example, terminology, benefits, barriers, facilitators, volumes and intensities for physical activity. No language restrictions were imposed. On the other hand, institutional documents, such as laws and public policies, without the population orientation profile, were not considered "guides".

Four strategies were adopted for the recovery of guides:

- Between June and July 2020: Manual searches on the websites of national education, sport and/or health agencies in 36 American countries: Canada, United States of America, Mexico, Antigua and Barbuda, Bahamas, Barbados, Belize, Costa Rica, Cuba, Dominica, El Salvador, Grenada, Guatemala, Haiti, Honduras, Jamaica, Nicaragua, Panama, Dominican Republic, Saint Lucia, Saint Kitts and Nevis, Sao Tome and Principe, Saint Vincent and the Grenadines, Trinidad and Tobago, Argentina, Bolivia, Brazil, Chile, Colombia, Ecuador, Guyana, Paraguay, Peru, Suriname, Uruguay and Venezuela. The search for these national agencies began by recognizing the official language of each country and applying terms, on the Google website, such as ministry, national agency, sports, health, education (in the country's official language and in English);

- In July 2020: Contact, via e-mail, with members of the Physical Activity Network of the Americas (RAFA/PANA; https://rafapana.org/), asking about the existence and, in affirmative cases, requesting local documents;

- Between July and August 2020: Complementary manual searches on the Google website, based 
on the terms "physical activity", "early childhood", "preschool", "screen time", "sedentary behavior", in addition to the name of the country (considering the spelling in the respective local languages);

- In September 2020: Contact with those responsible indicated by the Global Physical Activity Observatory (http://www.globalphysicalactivityobservatory. com/country-cards/), asking about the existence and, in affirmative cases, requesting the sharing of local guidelines.

Two independent researchers, with the support of a third researcher, read all guides in their entirety, in order to identify whether they adequately responded to the aforementioned inclusion criteria. Early childhood physical activity recommendations were considered, regardless of whether they are generally described or aimed at specific audiences (e.g., recommendations for parents, guardians, teachers, caregivers of children in early childhood).

The extraction worksheet was organized a priori into five distinct domains, established from previous references ${ }^{12,13}$ : (1) benefits; (2) dose; (3) types and examples; (4) guidelines for the practice of physical activity and (5) reduction of sedentary behavior. It was stipulated that the recommendations of the guides would be extracted according to their presentation in the original documents, classified, and organized into domains by two independent researchers, with the support of a third researcher. Once the consensus had been established, the descriptive synthesis was developed from the refinement of the extraction worksheet.

\section{Results}

Altogether, documents from 21 countries were retrieved. After reading, 17 of them were not included in the synthesis, as they did not contain specific mentions of the population of interest $(\mathrm{n}=10)$; for not being guides ( $\mathrm{n}$ =4); for not having the approval of the national education/sport/health agency $(\mathrm{n}=2)$ and for not mentioning physical activity $(n=1)$. The titles and the respective reasons for not including these documents are indicated in Supplementary Material 2. Thus, this synthesis was composed of four national physical activity guides with recommendations for early childhood ${ }^{8,14,15,16}$.

Table 1 shows the American countries with guides: Canada $^{8}$, Chile ${ }^{14}$, United States ${ }^{15}$ and Uruguay ${ }^{16}$. The documents were published between 2017 $8,14,15$ and $2018^{16}$, all endorsed by the national health agencies.
Documents retrieved through searches on websites and through contacts with researchers.

Assessed by the full texts $(\mathrm{n}=21)$

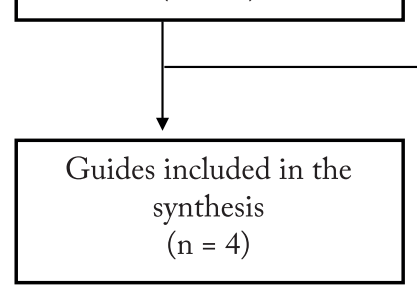
Deleted documents $(\mathrm{n}=17)$;
Does not present recom- mendations for the population of interest $(\mathrm{n}=$ $10)$
Does not qualify as a guide $(n=4)$;
Does not have a national agency seal $(n=2)$;
Does not mention physical activity $(\mathrm{n}=1)$

Figure 1 - Scope review flowchart

Table 1 - General information on physical activity guidelines from the American continent with recommendations for physical activity in early childhood.

\begin{tabular}{|c|c|}
\hline Country & $\begin{array}{l}\text { Title of the national guide (year of publication) and } \\
\text { endorsement(s) national agency(ies). }\end{array}$ \\
\hline Canada $^{12}$ & $\begin{array}{l}\text { Canadian 24-hour movement guidelines for the } \\
\text { early years ( } 0-4 \text { years): an integration of physical } \\
\text { activity, sedentary behaviour, and sleep ( } 2017) \text {. Guide } \\
\text { endorsed by the Public Health Agency of Canada. }\end{array}$ \\
\hline Chile $^{14}$ & $\begin{array}{l}\text { Recomendaciones para la práctica de actividad física } \\
\text { según curso de vida (2017). Guide endorsed by } \\
\text { the Ministerio del Deporte, Ministerio de Salud y } \\
\text { Ministerio de Educación de Chile. }\end{array}$ \\
\hline $\begin{array}{l}\text { United States of } \\
\text { America }^{15}\end{array}$ & $\begin{array}{l}\text { Physical activity guidelines for Americans }-2 \text { nd ed. } \\
\text { (2018). Guide endorsed by the U.S. Department of } \\
\text { Health and Human Services. }\end{array}$ \\
\hline Uruguay $^{16}$ & $\begin{array}{l}\text { ¡A MOVERSE! Guía de actividad física (2017). } \\
\text { Guide endorsed by the Ministerio de Salud y } \\
\text { Secretaria Nacional del Deporte de Uruguay. }\end{array}$ \\
\hline
\end{tabular}

Two guides also presented seals from other national agencies: Education and Sport ${ }^{14}$ and Sport ${ }^{16}$.

Regarding the domains, there was a greater number of recommendations about the benefits of physical activity $(\mathrm{n}=10)$ - Table 2 , in which all guides converge on the importance of physical activity in "help in controlling adequate weight and reducing the risk of obesity", as well as its role in "healthy growth and development" ${ }^{8,14-16}$. These guides also mention the importance of physical activity for babies ${ }^{8,14-16}$, in aiding motor coordination ${ }^{8,14,15}$, healthy growth of muscles and bones ${ }^{8,14,15}$, heart health ${ }^{8,14,15}$, quality of sleep $8,14,15$ and greater chance of active children becoming active adolescents and adults ${ }^{8,14,15}$.

Table 3 presents the recommendations on types and examples of physical activity $(n=7)$, highlighting the recommendations present in all included guides: "children must be physically active at various times of the day", offer of "joyful, safe, supervised and age-appropri- 
Table 2- Recommendations on the benefits of physical activity practice for children in early childhood $(n=4)$.

\begin{tabular}{|c|c|c|c|c|}
\hline \multirow{2}{*}{ Recommendations } & \multicolumn{4}{|c|}{ Countries } \\
\hline & $\mathrm{CAN}^{12}$ & $\mathrm{CHI}^{14}$ & $\mathrm{USA}^{15}$ & $\mathrm{URU}^{16}$ \\
\hline $\begin{array}{l}\text { Auxiliating your adequate body } \\
\text { weight control and reducing the risk } \\
\text { of obesity. }\end{array}$ & $\mathrm{X}$ & $\mathrm{X}$ & $\mathrm{X}$ & $\mathrm{X}$ \\
\hline $\begin{array}{l}\text { Healthy growth and development are } \\
\text { the main benefits. }\end{array}$ & $\mathrm{X}$ & $\mathrm{X}$ & $\mathrm{X}$ & $\mathrm{X}$ \\
\hline $\begin{array}{l}\text { Importance for all children, including } \\
\text { babies. }\end{array}$ & $\mathrm{X}$ & $\mathrm{X}$ & & $\mathrm{X}$ \\
\hline Helps motor coordination. & $\mathrm{X}$ & $\mathrm{X}$ & $\mathrm{X}$ & \\
\hline $\begin{array}{l}\text { Contributes for healthy muscle and } \\
\text { bone growth. }\end{array}$ & $\mathrm{X}$ & $\mathrm{X}$ & $\mathrm{X}$ & \\
\hline $\begin{array}{l}\text { Children who are physically active } \\
\text { tend to maintain physical activity } \\
\text { throughout their lives. }\end{array}$ & $\mathrm{X}$ & $\mathrm{X}$ & $\mathrm{X}$ & \\
\hline $\begin{array}{l}\text { Improves heart health and physical } \\
\text { condition. }\end{array}$ & $\mathrm{X}$ & $\mathrm{X}$ & $\mathrm{X}$ & \\
\hline Improves the quality of sleep. & $\mathrm{X}$ & $\mathrm{X}$ & $\mathrm{X}$ & \\
\hline $\begin{array}{l}\text { Helps in the integration and } \\
\text { development of psychological and } \\
\text { social skills. }\end{array}$ & $\mathrm{X}$ & $\mathrm{X}$ & & \\
\hline $\begin{array}{l}\text { Improves cognitive functions and } \\
\text { learning readiness. }\end{array}$ & $\mathrm{X}$ & $\mathrm{X}$ & & \\
\hline
\end{tabular}

Key: $\mathrm{CAN}=$ Canada; $\mathrm{CHI}=$ Chile USA = United States of America; URU = Uruguay.

ate physical activities" and "participation in games and structured activities" ${ }^{8,14-16}$. Recommendations specific to the different moments of early childhood can also be highlighted (up to one year; between one and two years old and; between three and five years old $)^{8,14-16}$.

Regarding the guidelines for practice $(n=6)$, available in Table 4, all guides recommend that "the support of parents and guardians or caregivers is essential for children to participate in games and other types of physical activity that encourage responsibility and autonomy"8,14-16. Other recommendations indicate that physical activities should be "happy, safe and supervised" $" 14,15$ and also consider the possibility of physical activity at home $e^{8,14,15}$. Table 4 also presents three recommendations on the dose of physical activity, stratified by different stages of early childhood (up to one year ${ }^{8,14}$; between one and two years old ${ }^{8}$ and; between three and five years old ${ }^{8,15}$ ).

In regard to sedentary behavior, most of the recommendations were identified in the Canadian guide ${ }^{8}$. Out of those, it is worth highlighting the following: "Less is better" (data not shown) $)^{8,14}$.

\section{Discussion}

Through the present study, the existence of four na-
Table 3-Recommendations on types and examples of physical activity for children in early childhood $(n=4)$.

\begin{tabular}{|c|c|c|c|c|}
\hline \multirow{2}{*}{ Recommendations } & \multicolumn{4}{|c|}{ Countries } \\
\hline & $\mathrm{CAN}^{12}$ & $\mathrm{CHI}^{14}$ & $\mathrm{USA}^{15}$ & $\mathrm{URU}^{16}$ \\
\hline $\begin{array}{l}\text { Children must be physically active in } \\
\text { several moments throughout the day. }\end{array}$ & $\mathrm{X}$ & $\mathrm{X}$ & $\mathrm{X}$ & $\mathrm{X}$ \\
\hline $\begin{array}{l}\text { Physical activities that are joyful, } \\
\text { safe, supervised and adequate to the } \\
\text { child's age. }\end{array}$ & $\mathrm{X}$ & $\mathrm{X}$ & $\mathrm{X}$ & $\mathrm{X}$ \\
\hline $\begin{array}{l}\text { Participation in games and structured } \\
\text { activities. }\end{array}$ & $\mathrm{X}$ & $\mathrm{X}$ & $\mathrm{X}$ & $\mathrm{X}$ \\
\hline $\begin{array}{l}\text { Children up to 1-year-old: games } \\
\text { involving activities that require the } \\
\text { child to stay faced down or seated } \\
\text { while moving their arms and legs } \\
\text { and that stimulate the child to reach, } \\
\text { hold, pull, push, crawl, roll, balance } \\
\text { themselves with or without support, } \\
\text { sit and stand and so on; }\end{array}$ & $\mathrm{X}$ & $\mathrm{X}$ & & $\mathrm{X}$ \\
\hline $\begin{array}{l}\text { Children between } 1 \text { and } 2 \text { years old: } \\
\text { games that involve activities such as } \\
\text { balancing themselves on both feet, } \\
\text { balancing on just one foot, crawling, } \\
\text { walking, running, jumping, climbing, } \\
\text { tossing, bouncing and holding and so on; }\end{array}$ & $\mathrm{X}$ & $\mathrm{X}$ & & $\mathrm{X}$ \\
\hline $\begin{array}{l}\text { Children between } 3 \text { and } 5 \text { five years } \\
\text { old: games that involve activities } \\
\text { such as walking, running, twisting, } \\
\text { kicking, tossing, jumping and walking } \\
\text { or climbing on objects and so. At } \\
\text { this age, physical activity can also } \\
\text { be done during the school's physical } \\
\text { education classes, swimming classes, } \\
\text { gymnastics, martial arts, dances } \\
\text { and sports or even through active } \\
\text { transport from one place to another, } \\
\text { such as walking or cycling, always } \\
\text { accompanied by parents or guardians. }\end{array}$ & $\mathrm{X}$ & $\mathrm{X}$ & & $\mathrm{X}$ \\
\hline $\begin{array}{l}\text { It is recommended that the child } \\
\text { learn how to swim, float, dive and } \\
\text { adapt to the aquatic environment. }\end{array}$ & & & & $\mathrm{X}$ \\
\hline
\end{tabular}

Key: $\mathrm{CAN}=\mathrm{Canada} ; \mathrm{CHI}=$ Chile; USA $=$ United States of America; URU = Uruguay.

tional physical activity guides with recommendations for children in early childhood was identified among the American countries. It is worth mentioning that all of these guides were also included in the synthesis of the previous research ${ }^{13}$, which, in all, identified ten countries with national physical activity guidelines. This reduced number of guides with physical activity recommendations aimed at early childhood can be justified by several factors, such as the recent formulation of international recommendations for this age group, the fact that many American countries still do not have lines of research and/or studies available in this age group ${ }^{17}$ and also by the limited budget of the agencies, which are generally intended to improve in- 
Table 4- Recommendations on practice guidelines and activity doses for children in early childhood $(n=4)$.

\begin{tabular}{|c|c|c|c|c|}
\hline \multirow{2}{*}{ Recommendations } & \multicolumn{4}{|c|}{ Countries } \\
\hline & $\mathrm{CAN}^{12}$ & $\mathrm{CHI}^{14}$ & $\mathrm{USA}^{15}$ & $\mathrm{URU}^{16}$ \\
\hline \multicolumn{5}{|l|}{ Guidelines for practicing physical activity } \\
\hline $\begin{array}{l}\text { Parents and guardians or caregiver } \\
\text { support is essential so that the } \\
\text { children engage in games and } \\
\text { other forms of physical activities } \\
\text { that stimulate responsibility and } \\
\text { autonomy. }\end{array}$ & $\mathrm{X}$ & $\mathrm{X}$ & $\mathrm{X}$ & $\mathrm{X}$ \\
\hline $\begin{array}{l}\text { Physical activities that are joyful, } \\
\text { safe supervised by parents/ } \\
\text { guardians and teachers and } \\
\text { adequate to the child's age. }\end{array}$ & $\mathrm{X}$ & $\mathrm{X}$ & $\mathrm{X}$ & \\
\hline $\begin{array}{l}\text { Children can be physically active } \\
\text { inside their homes, joining activities } \\
\text { with their relatives, especially if it } \\
\text { is not possible to practice outdoor } \\
\text { activities. }\end{array}$ & $\mathrm{X}$ & $\mathrm{X}$ & $\mathrm{X}$ & \\
\hline $\begin{array}{l}\text { Games or more structured activities } \\
\text { such as attending sport schools and } \\
\text { physical education classes. }\end{array}$ & $\mathrm{X}$ & $\mathrm{X}$ & $\mathrm{X}$ & \\
\hline $\begin{array}{l}\text { When parents and guardians } \\
\text { engage in physical activity with } \\
\text { their children, they stimulate these } \\
\text { children to be physically active. }\end{array}$ & $\mathrm{X}$ & $\mathrm{X}$ & $\mathrm{X}$ & \\
\hline $\begin{array}{l}\text { teachers should include movement, } \\
\text { active regional games and games } \\
\text { in general, as part of their school } \\
\text { activities' routines. }\end{array}$ & & $\mathrm{X}$ & $\mathrm{X}$ & \\
\hline \multicolumn{5}{|l|}{ Doses of physical activity } \\
\hline $\begin{array}{l}\text { Children p to } 1 \text { year old: at least } \\
30 \text { minutes per day with their } \\
\text { bellies faced down. The time can be } \\
\text { distributed throughout the day. }\end{array}$ & $\mathrm{X}$ & $\mathrm{X}$ & & \\
\hline $\begin{array}{l}\text { Children between } 3 \text { and } 5 \text { years } \\
\text { old: at least three hours per day of } \\
\text { physical activities of any intensity. }\end{array}$ & & & & \\
\hline $\begin{array}{l}\text { This includes at least } 1 \text { hour of } \\
\text { moderate to vigorous-intensity that } \\
\text { can be accumulated throughout } \\
\text { the day. }\end{array}$ & $\mathrm{X}$ & & $\mathrm{X}$ & \\
\hline $\begin{array}{l}\text { Children between } 1 \text { and } 2 \text { years } \\
\text { old: at least } 3 \text { hours per day of } \\
\text { physical activities of any intensity. } \\
\text { The time can be distributed } \\
\text { throughout the day. }\end{array}$ & $\mathrm{X}$ & & & \\
\hline
\end{tabular}

Key: $\mathrm{CAN}=\mathrm{Canada} ; \mathrm{CHI}=\mathrm{Chile} ; \mathrm{USA}=$ United States of America; URU = Uruguay.

dicators that have a greater impact on the country's health situation.

All included guides converged on recommendations about the importance of physical activity for weight control and healthy growth and development (e.g., benefits domain); about the importance of children being physically active at various times of the day, highlighting the offer of "joyful, safe, supervised and age-appropri- ate physical activities" and "participation in games and structured activities" (e.g., types and examples domain) and the support of parents and guardians or caregivers to encourage activities that promote responsibility and autonomy (e.g., practice orientation domain) $)^{8,14-16}$.

Apart from its strict relationship with human development and the apparent ease of adopting an active lifestyle, the promotion of physical activity, within the spectrum of health promotion, is a complex task that requires the development of actions and strategies that consider different individual and contextual factors of a person ${ }^{18,19}$. In recent decades, the guides started to address, as their central point, the active lifestyle, within people's preferences and possibilities ${ }^{20}$. Thus, it is worth mentioning that the American national guidelines are properly positioned in the current direction of the debate, since all the recommendations identified in the "benefits", "dose" and "sedentary behavior" domains are also present in the guidelines of the World Health Organization ${ }^{7}$. However, it should also be mentioned that the World Health Organization guide ${ }^{7}$ does not present recommendations related to the domains "practice guidelines" and "types and examples", except for the indication that "children must be physically active at various times of the day"7,8,14-16.

In a general perspective, it was possible to notice among the national guides the effort to guide physical activity beyond the prescriptive recommendations related to the volumes and intensities needed for the prevention/control of diseases and, in this sense, the expansion of its range of recommendations to other domains is suggested to future guidelines, which are also crucial for physical activity in this age group, such as: "social support of parents/guardians"21 and "built environment" 22 .

Regarding the social support of parents, given the decline in physical activity levels already in the first years of life $\mathrm{e}^{23}$ and the greater chance of active children becoming active adolescents, strategies that influence children's preference for physical activity are needed from early childhood $^{24}$, as well as the establishment of rules by the parents/guardians regarding its practice, respecting specificities such as gender and the child's stage in early childhood. Appropriate guidance, based on available knowledge, can help overcome barriers to physical activity.

It is also worth noting that children in early childhood depend directly on the family and/or other caregivers to have access to the appropriate spaces for the practice of physical activities ${ }^{25,26}$, since they do not have the autonomy to move to the leisure spaces present in the 
neighborhoods. Thus, future recommendations should propose specific guidelines for parents and caregivers about the role they can play regarding the access and permanence of children in the closest leisure environments, given that the interaction between parents-children or caregivers-children can be facilitate or restrict the regular practice of physical activity at early ages ${ }^{27}$.

In regard of the built environment and its relationship with the practice of physical activity by children in early childhood, the various leisure contexts built in preschools and/or neighborhoods may have relevance to the different patterns of physical activity behavior throughout the children's day, which vary in time, intensities and places of performance of activities ${ }^{28,29}$. Thus, the structure built in a neighborhood, through its characteristics (distance, aesthetics, safety), can impact the development of physical activity in childhood, which is essential for later stages of life ${ }^{30,31}$.

This work has some limitations, such as the absence of searches in electronic databases, considering previous experience on the difficulty of retrieving guides on these platforms and the inclusion of guides specifically approved by national education, sport and/or health agencies. During the process of searching for the materials, a Brazilian guide was recognized with recommendations for physical activity for early childhood, but endorsed by a scientific society ${ }^{32}$. It is worth justifying that the option for the seal of national agencies was due to the intention of carrying out a comparative analysis between the documents as a partial subsidy to the proposal of the Brazilian Guide. In addition, it is worth considering that sedentary behavior is a secondary outcome, analyzed from its identification in guides that contained recommendations for physical activity. However, this synthesis has the potential to present summarized data that were not identified in the previous study ${ }^{13}$ and, given the specificity of the American continent, it can serve as a starting point for the preparation of other physical activity guides.

Finally, this paper points to the existence, in the American continent, of four national physical activity guides with recommendations for children in early childhood. In addition, there was a predominance of recommendations on benefits, types and guidelines for the practice of physical activity. Considering that physical activity promotion strategies involve addressing individual and contextual factors, it is important that future national physical activity guidelines involve recommendations in domains that are determinants of physical activity in this age group, such as the support of primary caregivers and the built environment, in its access and possibilities.

\section{Conflict of interest}

The authors declare no conflict of interest.

\section{Funding}

This study was financed in part by the Coordenação de Aperfeiçoamento de Pessoal de Nível Superior - Brasil (CAPES). Brazilian Health Department, through the Decentralized Execution Term No. 56/2019 (project: 79224219002/2019; process: 25000.171034/2019-27).

\section{Author Contributions}

All authors contributed substantially to the study. Guerra $\mathrm{PH}$ participated in the conception of the central idea of the study; development of searches, assessment, extraction and analysis of data; writing of the final text. Souza Filho NA participated in the conception of the central idea of the study; development of searches, assessment, extraction and analysis of data; writing of the final text. Hardman CM, Martins CL, Queiroz DR, Silva LR, Wanderley Júnior RS, Sandreschi PF, Umpierre D participated in the data analysis; review of the final text. Barros MVG participated in project supervision; conception of the central idea of the study; development of searches, assessment, extraction and analysis of data; review of the final text.

\section{References}

1. McCrorie $P$, Martin A, Janssen X. Physical activity guidelines and recommendations. In: Brusseau TA, Fair-clough SJ, Lubans, DR, editors. The Routledge Handbook of Youth Physical Activity. New York: Routledge; 2020. p. 69-100.

2. Troiano RP, Stamatakis E, Bull FC. How can global physical activity surveillance adapt to evolving physical activity guidelines? Needs, challenges and future directions. Br J Sports Med. 2020;54(24):1468-73.

3. Milton K, Bauman AE, Faulkner G, Hastings G, Bellew W, Williamson C, Kelly P. Maximising the impact of global and national physical activity guidelines: the critical role of communication strategies. Br J Sports Med. 2020;54(24):1463-7.

4. Britto PR, Lye SJ, Proulx K, Yousafzai AK, Matthews SG, Vaivada T, et al. Nurturing care: promoting early childhood development. Lancet. 2017;389(10064):91-102.

5. Black MM, Walker SP, Fernald LCH, Andersen CT, DiGirolamo AM, Lu C, et al. Early childhood development coming of age: science through the life course. Lancet. 2017;389(10064):77-90.

6. Telama R, Yang X, Leskinen E, Kankaanpää A, Hirvensalo M, Tammelin T, et al. Tracking of physical activi-ty from early childhood through youth into adulthood. Med Sci Sports Exerc. 2014;46(5):955-62.

7. World Health Organization. Guidelines on physical activity, sedentary behaviour and sleep for children under 5 years of age. 2019. Available from: https://apps.who.int/iris/ handle/10665/311664. 
8. Jones R, Okely AD. Physical Activity Recommendations for Early Childhood. Encyclopedia on Early Child-hood Development. 2020. Available from: http://www.childencyclopedia.com/physical-activity/according-experts/ physical-activity-recommendations-early-childhood.

9. Canada-Canadian Society for Exercise Physiology[homepage on the Internet]. Canadian 24-hour movement guidelines: an integration of physical activity, sedentary behaviour, and sleep. Available from: https://csepguidelines.ca/.

10. Brasil. Ministério da Saúde. Secretaria de Atenção Primária à Saúde. Departamento de Promoção da Saúde. Guia de Atividade Física para a População Brasileira. 2021. Available from: https://bvsms.saude.gov.br/bvs/publicacoes/guia_ atividade_fisica_populacao_brasileira.pdf.

11. Silva LR, Hardman CM, Martins CL, Guerra PH, Souza Filho AN, Queiroz DR, et al. Atividade física para crianças de até 5 anos: Guia de Atividade Física para a População Brasileira. Rev Bras Ativ Fís Saúde. 2021;26:e0213.

12. Ramires VV, Becker LA, Sadovsky ADI, Zago AM, Bielemann RM, Guerra PH. Evolução da pesquisa epidemiológica em atividade física e comportamento sedentário no Brasil: atualização de uma revisão sistemática. Rev Bras Ativ Fis Saúde. 2014;19:529-30.

13. Guerra PH, Garcia LMT, Ribeiro EHC, Maretti ALR, Andrade DR, Florindo AA. Identificação e análise das diretrizes nacionais de atividade física nas Américas. Cien Saude Colet. 2021;26:2961-8.

14. Chile. Ministerio del Deporte; Ministerio de Salud; Ministerio de Educación. Recomendaciones para la prác-tica de actividad física según curso de vida. 2017. Available from: http://selloseligevivirsano.cl/wp-content/uploads/2019/03/ guia-de-recomendaciones-af-curso-de-vida.pdf.

15. Estados Unidos da América. United States Department of Health and Human Services. Physical activity guidelines for americans. 2nd edition. 2018. Available from: https:// health.gov/sites/default/files/2019-09/Physical_Activity_ Guidelines_2nd_edition.pdf.

16. Uruguai. Ministerio de Salud; Secretaria Nacional del Deporte. ¡A MOVERSE! Guía de actividad física. 2017. Available from: https://www.paho.org/uru/dmdocuments/ WEB\%20-\%20Guia\%20de\%20actividad\%20fisica2\%20 -\%20MSP-compressed.pdf.

17. Guerra PH, Barbosa Filho VC, Almeida A, Silva LS, Pinto MTV, Leonel RM, et al. Systematic review of physical activity and sedentary behavior indicators in South-American preschool children. Rev Paul Pediatr. 2019;38:e2018112.

18. Knuth AG, Silva ICM, Mielke GI. Promoção da saúde: um convite à releitura de imprecisões teóricas na área de Atividade Física e Saúde. Rev Bras Ativ Fís Saúde. 2018;23:e0032.

19. Bingham DD, Costa S, Hinkley T, Shire KA, Clemes SA, Barber SE. Physical Activity During the Early Years: A Systematic Review of Correlates and Determinants. Am J Prev Med. 2016;51(3):384-402.

20. Ding D, Mutrie N, Bauman A, Pratt M, Hallal PRC, Powell KE. Physical activity guidelines 2020: compre-hensive and inclusive recommendations to activate populations. Lancet. 2020;396(10265):1780-2.
21. Xu H, Wen LM, Rissel C. Associations of parental influences with physical activity and screen time among young children: a systematic review. J Obes. 2015;2015:546925.

22. Christian H, Ball SJ, Zubrick SR, Brinkman S, Turrell G, Boruff B, et al. Relationship between the neigh-bourhood built environment and early child development. Health Place. 2017;48:90-101.

23. Jones RA, Hinkley T, Okely AD, Salmon J. Tracking physical activity and sedentary behavior in childhood: a systematic review. Am J Prev Med. 2013;44(6):651-8.

24. Hinkley T, Salmon J, Okely AD, Hesketh K, Crawford D. Correlates of preschool children's physical activity. Am J Prev Med. 2012;43(2):159-67.

25. Eichinger M, Schneider S, De Bock F. Subjectively and objectively assessed social and physical environmental correlates of preschoolers' accelerometer-based physical activity. Int J Behav Nutr Phys Act. 2017;14,153.

26. French SA, Sherwood NE, Mitchell NR, Fan Y. Park use is associated with less sedentary time among low-income parents and their preschool child: The NET-Works study. Prev Med Rep. 2017;5:7-12.

27. Fan Y, Chen Q. Family functioning as a mediator between neighborhood conditions and children's health: evi-dence from a national survey in the United States. Soc Sci Med. 2012;74(12):1939-47.

28. Ruiz RM, Sommer EC, Tracy D, Banda JA, Economos CD, $\mathrm{JaKa} \mathrm{MM}$, et al. Novel patterns of physical activ-ity in a large sample of preschool-aged children. BMC Public Health. 2018;18(1):242.

29. Aguilar-Farias N, Martino-Fuentealba P, Espinoza-Silva M. Objectively measured physical activity and sed-entary behaviour patterns in chilean pre-school children. Nutr Hosp. 2015;32(6):2606-12.

30. An R, Shen J, Yang Q,Yang Y.Impact of built environment on physical activity and obesity among children and adolescents in China: a narrative systematic review. Journal of sport and health science. 2019;8(2):153-69.

31. Carlin A, Perchoux C, Puggina A, Aleksovska K, Buck C, Burns C, et al. A life course examination of the physical environmental determinants of physical activity behaviour: A "Determinants of Diet and Physical Activi-ty" (DEDIPAC) umbrella systematic literature review. PLoS One. 2017;12(8):e0182083.

32. Sociedade Brasileira de Pediatria. Promoção da Atividade Física na Infância e Adolescência. 2017. Available from: https://www.sbp.com.br/fileadmin/user_upload/19890eMO-Promo_AtivFisica_na_Inf_e_Adoles-2.pdf.

Received: $21 / 05 / 2021$

Approved: 08/09/2021

Quote this article as:

Guerra PH, Souza Filho AN, Hardman CM, Martins CL, Queiroz DR, Silva LR, Sandreschi PF, Wanderley Junior RS, Umpierre D, Barros MVG. National guidelines for physical activity in early childhood in American countries: a scoping review. Rev Bras Ativ Fís Saúde. 2021;26:e0228. DOI: 10.12820/rbafs.26e0228 


\section{Supplementary Material}

Supplementary Material 1 - Indication of the items on the PRISMA checklist answered in the article.

\begin{tabular}{|c|c|c|c|}
\hline Section & Item & PRISMA-ScR checklist item & Reported on page \# \\
\hline \multicolumn{4}{|c|}{ Title } \\
\hline Title & 1 & Identify the report as a scoping review. & 1 \\
\hline \multicolumn{4}{|c|}{ Abstract } \\
\hline Structured summary & 2 & $\begin{array}{l}\text { Provide a structured summary that includes (as applicable): background, objectives, eligibility } \\
\text { criteria, sources of evidence, charting methods, results, and conclusions that relate to the review } \\
\text { questions and objectives. }\end{array}$ & 1 \\
\hline \multicolumn{4}{|c|}{$\begin{array}{l}\text { Introduction } \\
\end{array}$} \\
\hline Rationale & 3 & $\begin{array}{l}\text { Describe the rationale for the review in the context of what is already known. Explain why the } \\
\text { review questions/objectives lend themselves to a scoping review approach. }\end{array}$ & $3-4$ \\
\hline Objectives & 4 & $\begin{array}{l}\text { Provide an explicit statement of the questions and objectives being addressed with reference to } \\
\text { their key elements (e.g., population or participants, concepts, and context) or other relevant key } \\
\text { elements used to conceptualize the review questions and/or objectives. }\end{array}$ & 4 \\
\hline \multicolumn{4}{|c|}{ Methods } \\
\hline Protocol and registration & 5 & $\begin{array}{l}\text { Indicate whether a review protocol exists; state if and where it can be accessed (e.g., a Web } \\
\text { address); and if available, provide registration information, including the registration number. }\end{array}$ & 5 \\
\hline Eligibility criteria & 6 & $\begin{array}{l}\text { Specify characteristics of the sources of evidence used as eligibility criteria (e.g., years } \\
\text { considered, language, and publication status), and provide a rationale. }\end{array}$ & $5-6$ \\
\hline Information sources* & 7 & $\begin{array}{l}\text { Describe all information sources in the search (e.g., databases with dates of coverage and } \\
\text { contact with authors to identify additional sources), as well as the date the most recent search } \\
\text { was executed. }\end{array}$ & $5-6$ \\
\hline Search & 8 & $\begin{array}{l}\text { Present the full electronic search strategy for at least } 1 \text { database, including any limits used, such } \\
\text { that it could be repeated. }\end{array}$ & 6 \\
\hline $\begin{array}{l}\text { Selection of sources of } \\
\text { evidence } \dagger\end{array}$ & 9 & $\begin{array}{l}\text { State the process for selecting sources of evidence (i.e., screening and eligibility) included in the } \\
\text { scoping review. }\end{array}$ & 6 \\
\hline Data charting process $\ddagger$ & 10 & $\begin{array}{l}\text { Describe the methods of charting data from the included sources of evidence (e.g., calibrated } \\
\text { forms or forms that have been tested by the team before their use, and whether data charting } \\
\text { was done independently or in duplicate) and any processes for obtaining and confirming data } \\
\text { from investigators. }\end{array}$ & $5-7$ \\
\hline Data items & 11 & $\begin{array}{l}\text { List and define all variables for which data were sought and any assumptions and } \\
\text { simplifications made. }\end{array}$ & $6-7$ \\
\hline $\begin{array}{l}\text { Critical appraisal of individual } \\
\text { sources of evidence } \S\end{array}$ & 12 & $\begin{array}{l}\text { If done, provide a rationale for conducting a critical appraisal of included sources of evidence; } \\
\text { describe the methods used and how this information was used in any data synthesis (if } \\
\text { appropriate). }\end{array}$ & $6-7$ \\
\hline Synthesis of results & 13 & Describe the methods of handling and summarizing the data that were charted. & $6-7$ \\
\hline \multicolumn{4}{|c|}{ Results } \\
\hline $\begin{array}{l}\text { Selection of sources of } \\
\text { evidence }\end{array}$ & 14 & $\begin{array}{l}\text { Give numbers of sources of evidence screened, assessed for eligibility, and included in the } \\
\text { review, with reasons for exclusions at each stage, ideally using a flow diagram. }\end{array}$ & $\begin{array}{l}\text { 7; figura 1; material } \\
\text { suplementar } 2\end{array}$ \\
\hline $\begin{array}{l}\text { Characteristics of sources of } \\
\text { evidence }\end{array}$ & 15 & $\begin{array}{l}\text { For each source of evidence, present characteristics for which data were charted and provide the } \\
\text { citations. }\end{array}$ & Tabelas 1-4 \\
\hline $\begin{array}{l}\text { Critical appraisal within } \\
\text { sources of evidence }\end{array}$ & 16 & If done, present data on critical appraisal of included sources of evidence (see item 12). & $7-8$ \\
\hline $\begin{array}{l}\text { Results of individual sources of } \\
\text { evidence }\end{array}$ & 17 & $\begin{array}{l}\text { For each included source of evidence, present the relevant data that were charted that relate to } \\
\text { the review questions and objectives. }\end{array}$ & $7-8$ \\
\hline Synthesis of results & 18 & $\begin{array}{l}\text { Summarize and/or present the charting results as they relate to the review questions and } \\
\text { objectives. }\end{array}$ & $7-8$; tabelas $1-4$ \\
\hline \multicolumn{4}{|c|}{ Discussion } \\
\hline Summary of evidence & 19 & $\begin{array}{l}\text { Summarize the main results (including an overview of concepts, themes, and types of evidence } \\
\text { available), link to the review questions and objectives, and consider the relevance to key groups. }\end{array}$ & $8-12$ \\
\hline Limitations & 20 & Discuss the limitations of the scoping review process. & 11 \\
\hline Conclusions & 21 & $\begin{array}{l}\text { Provide a general interpretation of the results with respect to the review questions and } \\
\text { objectives, as well as potential implications and/or next steps. }\end{array}$ & $11-12$ \\
\hline \multicolumn{4}{|c|}{ Funding } \\
\hline Funding & 22 & $\begin{array}{l}\text { Describe sources of funding for the included sources of evidence, as well as sources of funding } \\
\text { for the scoping review. Describe the role of the funders of the scoping review. }\end{array}$ & 4 \\
\hline
\end{tabular}


Supplementary Material 2 - List of documents that were not included in the synthesis, with respective reasons $(\mathrm{n}=17)$

\begin{tabular}{|c|c|c|}
\hline Country & Title & Reason for non-inclusion \\
\hline Antigua and Barbuda & National Business Plan for Health & Does not qualify as a guide \\
\hline Bahamas & Preschool curriculum 2007 & Does not qualify as a guide \\
\hline Bolivia & Guía local de educación para la vida en la promoción de la salud. & Does not mention physical activity \\
\hline Brazil & Manual de Orientação - Promoção da Atividade Física na Infância e Adolescência & Does not have a national agency seal \\
\hline Colombia & Orientaciones para la gestión territorial de la promoción de la actividad física & $\begin{array}{l}\text { Does not present recommendations for the } \\
\text { population of interest }\end{array}$ \\
\hline Costa Rica & Plan nacional de actividad física y salud 2011-2021 & $\begin{array}{l}\text { Does not present recommendations for the } \\
\text { population of interest }\end{array}$ \\
\hline Cuba & Plan educativo - primera infancia & Does not have a national agency seal \\
\hline El Salvador & Ley general de los deportes de E1 Salvador & Does not qualify as a guide \\
\hline Ecuador & Guía de actividad física dirigida al personal de salud ii & $\begin{array}{l}\text { Does not present recommendations for the } \\
\text { population of interest }\end{array}$ \\
\hline Honduras & Guia de actividad física para facilitadores de salud & $\begin{array}{l}\text { Does not present recommendations for the } \\
\text { population of interest }\end{array}$ \\
\hline Jamaica & Physical activity guide and toolkit for the workplace & $\begin{array}{l}\text { Does not present recommendations for the } \\
\text { population of interest }\end{array}$ \\
\hline Mexico & Programa de acción específico: alimentación y actividad física 2013-2018 & $\begin{array}{l}\text { Does not present recommendations for the } \\
\text { population of interest }\end{array}$ \\
\hline Paraguai & Política de promoción de la actividad física com enfoque en el ciclo vital & $\begin{array}{l}\text { Does not present recommendations for the } \\
\text { population of interest }\end{array}$ \\
\hline Peru & Módulo educativo: promoción de la actividad física para la salud & $\begin{array}{l}\text { Does not present recommendations for the } \\
\text { population of interest }\end{array}$ \\
\hline Dominican Republic & Programa de gobierno 2016-2020 & Does not qualify as a guide \\
\hline Suriname & National action plan for the prevention and control of noncommunicable diseases & $\begin{array}{l}\text { Does not present recommendations for the } \\
\text { population of interest }\end{array}$ \\
\hline Trinidad and Tobago & $\begin{array}{l}\text { National strategic plan for the prevention and control of non-communicable } \\
\text { diseases: Trinidad and Tobago } 2017-2021\end{array}$ & $\begin{array}{l}\text { Does not present recommendations for the } \\
\text { population of interest }\end{array}$ \\
\hline
\end{tabular}

